\title{
How to Improve the Manpower Shortage of Coastal Hotels Under the COVID-19 Epidemic Environment! Explore the Effectiveness of the Hotel Internship Training System
}

\section{Bing-Wang Xue}

Wuhan Business University

Hsiao-Hsien Lin ( $\square$ chrishome12001@yahoo.com.tw )

JiaYing University https://orcid.org/0000-0001-8360-3998

Chao-Chien Chen

AISA University

\section{Peng-Yeh Lee}

National Yunlin Institute of Technology: National Yunlin University of Science and Technology

Chin-Hsien Hsu

National Chinyi University of Technology: National Chin-Yi University of Technology

\section{Research Article}

Keywords: CSR, Social entrepreneurship, Employee well-being, Sustainable business models

Posted Date: September 20th, 2021

DOl: https://doi.org/10.21203/rs.3.rs-884641/v1

License: (ㅇ) (i) This work is licensed under a Creative Commons Attribution 4.0 International License. Read Full License 


\section{Abstract}

This study aimed to investigate the key factors of sustainability of hotel social responsibility from the effectiveness of the hotel intern training system. Using a mixed research method, a sample was first selected by purposive sampling, and 280 questionnaires were obtained by snowballing from September 2019 to February 2020. Using Statistical package for social sciences (SPSS, AMOS) IBM 22.0 software, the reliability of the questionnaires was confirmed by the CFA method, examined by Pearson Correlation Analysis, and then the opinions of hoteliers, experts, and senior employees on the questionnaire results were obtained by interview method and finally, the data were compiled and analyzed by multivariate verification. The study found that: Chinese hoteliers are unable to stabilize their employees' motivation and fulfill their internal social responsibility due to insufficient human resource training system, welfare benefits, job rotation mechanism, and poorly defined reward and punishment system. In order to stabilize the implementation of perfect internal corporate responsibilities for entrepreneurs, it is necessary to strengthen corporate culture promotion, improve the existing promotion system, increase employee benefits, and adjust the working environment and facilities. In this way, even in a harsh working environment, it can still increase employees' recognition of the company, improve work performance, and increase employees' willingness to stay.

\section{Introduction}

Under the trend of globalization, in order to achieve sustainable development, it is the current tendency of corporate management for enterprises to strengthen their social responsibility to achieve the goal of sustainable development, in addition to making profits from operations and maintaining basic consumption costs (Androniceanu 2019). While corporate responsibility mainly involves responsibilities to stakeholders, corporate social responsibility can be divided into external responsibility and internal responsibility, with external responsibility being the interaction with society as a whole and the surrounding community, internal social responsibility refers to the care and interaction with employees (Singh and Misra 2021). In response to operational needs, companies recruit local residents to serve the company and utilize the labor and technology they receive to maintain the operational base and achieve business goals (Wu 2017). In order to achieve stable development, the organization treats employees fairly, provides them with a safe and carefree working environment, improves their personal and family quality of life, and seeks to enhance their loyalty to the organization, which in turn promotes the company's popularity, attracts consumers to spend money, increases the company's total return on assets (Chi et al. 2016), and promotes local development. Such a two-way profit approach to stabilize corporate and community development, provide employment opportunities for residents, and improve the quality of life is a corporate social responsibility (Wu 2017) and also a major concern of society and the public (Uduji and Okolo-Obasi 2019).

The hotel industry responds to the development of the tourism industry and demand, according to statistics, the total number of chain and independent hotels worldwide has reached 886,900 , with a steady growth towards 1.5\% from 2015-2019 (Shenzhen Qianzhan Information Co., Ltd 2020), which shows that the hotel industry is booming year by year. China has been developing the tourism since 1978. In recent years, it has actively established regional tourism facilities and improved transportation, hoping to promote rural development and revitalize the local economy. The development of the tourism industry has become one of China's emerging economic pillars (Li 2019b; Qiu 2008), and the hotel industry has risen and expanded rapidly in China. According to statistics, China attracted about 5,539 million domestic and foreign tourists in 2018. Therefore, the investment 
in the domestic tourism has reached more than 700 billion yuan and 10,667 star-rated hotels have been built (Ministry of Culture and Tourism of the People's Republic of China 2019). In addition, over 2 million employees have been recruited for tourism (Gao 2007). The number of people working in service-providing industries accounts for $47.4 \%$ of all those in employment in China, providing services for domestic and foreign tourists. The annual tourism revenue reached 5.97 trillion yuan in 2019 , contributing $11.4 \%$ of the year's GDP (Tang 2019), showing that China's tourism has been developing rapidly.

Although tourism has become China's main source of income in recent years, driven coastal cities and promoted business opportunities in the hotel industry, the tourism development and construction effects in China have been uneven due to changes in the global tourism model, coupled with tourism being labor-intensive and young people not much willing to work in tourism (Body and Hogg 2019), resulting in a shortage of hotel manpower (Hotel Industry Research Center, Zhongrui Hotel Management College 2018). In order to solve the manpower shortage, Chinese governments have been committed to investing in personnel training for tourism. There have been about 3.81 million graduates recruited to tourism each year (Ministry of Education of China 2020). In addition, the industry has planned accordingly, sought industry-academia cooperation, and signed relevant agreements, to provide internship training for recent graduates in hotels, hoping to cultivate talents (Leonchuk and Gray 2019) to meet the tourism manpower requirement. In general, the internship has been designed to solve the manpower shortage (Yunfei and Qin 2019), matching the hotel with the vocational school and making plans for students in school to receive training at a hotel for the sake of early adjustment and study. However, this has also been to provide basic service work manpower to solve the manpower shortage the hotel industry has faced, and then the two parties could jointly cultivate professional talents to satisfy the manpower requirement and further the professional training for hotels (Hotel Industry Research Center, Zhongrui Hotel Management College 2018; Leonchuk and Gray 2019; Ministry of Education of China 2020). This has been the trend in the modern hotel industry.

However, according to the survey it was found that although companies have invited cooperation from schools, in the hope that schools may provide students with theoretical knowledge acquired from school as high-quality manpower for the industry and relieve the manpower shortage, there is still a labor shortage due to 1 . The fact that the qualification for working at a hotel has been lowered but the entry requirements of the management are difficult. 2. Irregular work hours and physically demanding work. 3. Manpower shortage in physically demanding jobs. 4. Monotonous training and low effectiveness. 5. Student's major and technology that do not meet job requirements. 6. Company's low willingness to employ professionals. 7. Company's low willingness to retain interns. 8. Low salary and slow promotion. 9. Difficulty to retain middle management and service personnel. 10. High degree of staff turnover. 11. A lack of uniformity between power and responsibility of senior management (Yunfei and Qin 2019). In addition, with the raging COVID-19 virus, there were 21,916,639 coronavirus cases in 123 countries around the world. The severe pandemic has hit the global tourism badly, the tourists have had no willingness to travel (Foo et al. 2020; Hsu et al. 2020), job opportunities for tourism employees plummeted, and their physical and mental health has been affected under the attack of the virus (Foo et al. 2020a, b), and many have been forced to change jobs, exacerbating manpower shortage in tourism. As a result, there have been severe manpower shortages in various departments of the hotel, and the number of vacancies has been large. It is urgent to increase manpower (Yunfei and Qin 2019), find the key factors in the decrease of manpower (Hotel Industry Research Center, Zhongrui Hotel Management College 2018, 2019), so as to maintain the internal development and operation of the hotel. 
Companies strengthen their responsibility to their employees from their perspective and realize corporate social responsibility through highly committed human resource management measures. The enterprise side fully understands the strengths and weaknesses of the enterprise and enhances the work results of employees through the psychological sense of belonging at the mental level of individuals (Wu 2017), and establishes perfect human resource management measures such as recruitment and selection, education, training and development, job autonomy, decision-making participation, performance management, performance reward system, high salary system, employee welfare, promotion, employee participation and job security (Kwon et al. 2010), which can bring positive employee behavior, enhance employee loyalty (Nishii et al. 2008), and increase the willingness to stay. This not only can solve the problem of insufficient manpower and high turnover rate in hotel enterprises (Gursoy et al. 2008; Tan et al. 2020), but also can re-provide residents with stable job security, maintain community development, and fulfill corporate social responsibility (Body and Hogg 2019; Tang 2019).

The problem of manpower shortage and high turnover rate in hotel enterprises can be discussed in terms of finding ways to retain talents, starting from the job satisfaction and loyalty of employees (Gupta and Mikkilineni 2018), especially university intern employees trained by hotels, which is one of the main sources of manpower for enterprises and the cornerstone of manpower needed for the development of hotel industry in the country. Strong loyalty is helpful for employees to identify with the company, proactively solve problems and assist the company to quickly complete operational goals (Farrukh et al. 2017). On the other hand, great job satisfaction is helpful to improve work efficiency and increase employees' willingness to stay (Awad and Alhashemi 2012), so exploring interns' job satisfaction and loyalty is helpful to get answers. Many studies on employee satisfaction and loyalty in enterprises (Abdullah et al. 2011; Al-Refaie 2015; Amin et al. 2017; Said et al. 2020) are carried out from various perspectives. After the outbreak of the pandemic, the impact of COVID-19 on the management of the hotel industry is the main focus (Baum and Hai 2020; Dube et al. 2021; Hao et al. 2020; Jiang and Wen 2020). Few studies on employee satisfaction and loyalty have been carried out from the perspective of human resources, solving manpower shortage and dealing with the foreseeing challenges posed by the pandemic. There have been many studies examining the effectiveness of corporate human resource systems from the employee's point of view in terms of job satisfaction and loyalty perceptions (Sabuhari et al. 2020), and then examining the effectiveness of social responsibility within hotel enterprises (Wang et al. 2020; Wong and Kim 2020). There have been many studies examining related issues in the COVID-19 environment (Agarwal 2020; Parker 2020), but few studies use a mixed research approach to collect multi-dimensional information to examine new or intern employees (Jiang and Wen 2020), to analyze the key factors for the sustainability of the social responsibility of island hotels. Therefore, the researcher believes that by examining the human resource training system from the perspective of hotel intern employees, and then understanding the effectiveness of hotel enterprises in promoting social responsibility, and analyzing the key factors for sustainable development of hotel enterprises, the results will be beneficial for hotel operators to adjust their human resource management system, uphold corporate social responsibility, and create room for sustainable development conditions when facing a severe development environment in the future.

In the light of the above analysis and discussion, the main purpose of this study was to examine the hotel talent training system from both job satisfaction and loyalty awareness from the perspective of hotel intern employees, to understand the effectiveness of island hotels enterprises in promoting social responsibility, and to analyze the key factors for sustainable development of hotel enterprises. 


\section{Literture Review}

\section{Human resource management and CSR}

The key to HR management decisions is how to utilize human resources to realize organizational strategies and goals and to properly manage the problems between employees and the company (Čančer and Šarotar Žižek 2017). The major targets of fundamental HR recruitment are local citizens, and HR management measures are used to recruit and select talents, train them, utilize them, and retain them for the organization, to increase employee productivity, reducing costs, improve work quality, and enhancing the organization's competitive advantage and employees' adaptability within the organization (Wu 2017). In this way, the productivity of the organization is maximized, and social responsibility and commitment are maintained in the face of internal and external pressures on the organization.

Human resource management in the hospitality industry must implement initiatives that help organizations achieve and maintain a competitive advantage (Friedman 2007). Although the main target of implementation is people, its impact includes the whole organization itself, as well as the organization's social commitment and responsibility to internal and external parties (Wu et al. 2010). Human resource management affects the behaviors, attitudes, performance policies, practices, and systems of organization members (Noe et al. 2003) to ensure that the efforts of employees, organizational performance, and market competitiveness complement each other and grow together (Marlow 2006). By recognizing the employment relationship between the company and its employees and reordering the management methods (Huemann et al. 2007), the company is required to fulfill its social responsibility and strengthen its competitive advantage so that the hotel can operate sustainably. It can be seen that examining the human resource system of hotels from the perspective of employees can help to understand the current status of the corporate human resource training system and further explore the degree of implementation of corporate social responsibility.

\section{Employee loyalty}

Grass-roots employees are the cornerstone of enterprise development (Yee et al. 2010). For the hotel industry, grass-roots employees are the front line workers facing consumers, providing tourists with high-quality services, arousing the feeling of consumer satisfaction (Li 2019a), the key factor in improving consumers' willingness to repurchase and corporate image indirectly. However, the hotel industry in China is facing the problem of high degree of labor turnover (Hotel Industry Research Center, Zhongrui Hotel Management College 2018, 2019), which is impacting the current development of the tourism and hotel industry, and needs to be addressed immediately. Nevertheless, when companies want hire qualified employees, the latter also desire to join a good company. This is the law of supply and demand (Yukongdi and Shrestha 2020). If a company wants to develop sustainably, it is necessary to make employees remain loyal to the company. The group coherence in an enterprise is a kind of identification with it and can be said to be a kind of belief, which can be called loyalty.

Loyalty is the key factor that affects employees' choice to stay in the organization. Employees loyal to the company are more efficient and actively assist the company in solving operational challenges, so as to promote the company to successfully complete its operational goals (Foster et al. 2008). Although interns still studying at school enter the workforce for the sake of early adjustment and study, they actually provide basic services to solve the manpower shortage in the hotel industry (Yunfei and Qin 2019), so they can be regarded as frontline employees. Although the interns have insufficient experience, they actually do work assigned to them during the 
internship and experience things for themselves in order to learn from them. The internship not only can be helpful for the school to achieve its purpose of promoting students' learning experience in workplace but also enhance the motivation of students to enter workforce for learning and working. In addition, the basic level service manpower shortage can be solved and companies can also use this to discover available talents, to cultivate core manpower (Hotel Industry Research Center, Zhongrui Hotel Management College, 2018; Leonchuk and Gray 2019; Ministry of Education of China, 2020; Yunfei and Qin 2019).

However, regardless of the status of employees, how companies retain them, meet the requirement of manpower, and increase loyalty are the main factors for business growth and sustainability (Farrukh et al. 2019). In addition, the success of a company or organization largely depends on the loyalty of employees (Larivière et al. 2016) among the key factors. It is important for companies to retain employees in current business environment (Farrukh et al. 2017). If a hotel wants to improve operational effectiveness, accomplish corporate goals, and retain employees, increasing employee loyalty will be essential (Allen and Grisaffe 2001).

The improvement of loyalty can be affected by company organization, promotion, job transfer, retention or layoffs (Farrukh et al. 2019), and viewed from several perspectives such as the interaction between supervisors and employees, and the trust and support of enterprises to subordinates and employees (Bushra et al. 2011). So far as an enterprise concerned, employees are on the front line to serve customers on behalf of the enterprise, and they are also the main medium for promoting consumers to contact the company's products and services. Companies hope that employees have a strong identification with them and the employee loyalty can be increased, and make their attitudes consistent with the industry's goals, so as to improve work efficiency and achieve operational goals (Allen and Grisaffe 2001). On the other hand, employees hope that they can gain the company's recognition for their hard work, have a steady job and earn a living, and improve the quality of life. Enterprises and employees interact with each other and have a very close relationship (Yukongdi and Shrestha 2020). It can be seen that the universal loyalty of employees will help enterprises to increase their willingness to stay and solve the problem of manpower loss. In addition, investigating the key factors affecting employee loyalty will find more detailed answers. However, obtaining universal loyalty is not easy because different personal characteristics and work environments can cause interference (Smith et al. 1969), so exploring the nature of employee loyalty will help obtain answers.

\section{Job satisfaction}

Job satisfaction refers to the difference between the actual pay of employees and their expected pay in a specific work environment. It is a kind of feeling about the work content, environment and the gains obtained (Liu et al. 2019; Seashore and Taber 2001). For company owners, they all hope to hire employees with high work efficiency, but satisfaction will affect work effectiveness, because job satisfaction affects employees' work effectiveness. High job satisfaction will lead to the retention of employees with positive work behaviors. On the contrary, low job satisfaction cause negative results (Cumbey and Alexander 1998; Foo et al. 2020a).

The key factors affecting job satisfaction can be viewed from several perspectives such as the emotions among workers (Abdullah et al. 2011), the working environment, salary and benefits (Farrukh et al. 2019), and the expectations of business organizations (Foy et al. 2019). A good fellowship and working environment help workers reduce their psychological pressure (Yao et al. 2019). Earning adequate salary and benefits can help employees improve their current living conditions (Reynolds 2019) and increase their motivation for work. 
Moreover, all employees hope to get a steady job and will be guaranteed a normal personal or family life for a long time. Therefore, if they can satisfy the company's expectations or have its promise, their enthusiasm for work will be enhanced (Shanock et al. 2019). So, it can be seen that the level of job satisfaction affects the enthusiasm and effectiveness of employees.

Good work performances can help improve work efficiency and achieve operational goals (Foster et al. 2008). Therefore, companies expect employees to work efficiently, and all employees can produce good work performances. However, universal behavior is a kind of expectation and goal, and different differences will interfere with personal feelings due to differences in personal characteristics and work environments (Smith et al. 1969), so exploring the nature of employee satisfaction will help to obtain answers.

\section{Related to job satisfaction and Employee loyalty}

Employee loyalty to a company is the employee's commitment to the company. Loyal employees are willing to assist the company to meet the challenge and get due rewards for this (Farrukh et al. 2019; Foster et al. 2008). However, loyalty is not a panacea. Even if the company makes perfect policies or employees have high loyalty, when they can't get rewards they deserve, to meet their daily needs and enable the company achieving operational goals, their identification with the company cannot be improved and the company owners' trust in employees will reduce (Reynolds 2019). Therefore, if the job satisfaction of employees can be improved, the enthusiasm for work can be stimulated and their identification with the enterprise can be strengthened, the work efficiency can be improved and the goals and standards of the company's employment can be achieved. It can be inferred from this that for companies or interns to remain, interns' loyalty and job satisfaction will be close and inseparable key factors. Therefore, if companies can fulfill their internal social responsibility and plan and improve their human resource management system (Friedman 2007) to meet the actual needs of business operation and employees, it will promote the consensus between companies and employees and achieve the winwin goal (Marlow 2006). Hence, the researchers believed that it would be more effective to promote a consensus between the employees and the human resource management system in the current job content of the hotel. Accordingly, hypotheses 1 and 2 were set: hotel employees showed consistent perceptions regarding their satisfaction with their current job content and corporate loyalty.

Studies have confirmed that employee loyalty would be affected by job satisfaction (Amin et al. 2017), but the job performance derived from employee job satisfaction is the key to corporate organizations to retain highly efficient employees (Friedman 2007). Because job satisfaction affects work enthusiasm (Foster et al. 2008), if employees' identification with the company can be strengthened, not only can work efficiency be improved, but also service quality can be enhanced (Farrukh et al. 2019). It can be seen that job satisfaction and employee loyalty affects each other. Hence, the research hypothesis 3 was: there is a mutual influence between employee job satisfaction and loyalty.

However, the key factors affecting job satisfaction and loyalty are diverse. Among them, the trust and support of supervisors and employees is the key to establishing loyalty (Bushra et al. 2011), which affects employees' willingness to stay and their psychological feelings (Yao et al. 2019). For companies, loyalty is the employee's commitment to the company. Employees loyal to the company are willing to help it meet challenges and get the rewards they deserve (Liu et al. 2019), and employees with high work efficiency will be trusted by company, which then will empower them and actively train them to take on the responsibility. Therefore, it can be 
understood that if the company's expectations can be met and work efficiency promoted, the current working environment, salary, organizational commitment, and interpersonal relationship will be improved. As a result, it is inferred that the degree of employees' satisfaction with their working environment, salary, identification with the company, and interpersonal relationships affects the level of loyalty. Then, Hypothesis 4-7 is put forward: employees' satisfaction with their working environment $(\mathrm{H} 4)$, salary $(\mathrm{H} 5)$, organizational commitment $(\mathrm{H} 6)$ and interpersonal relationship (H7) have a positive and significant impact on job loyalty.

Furthermore, employee performance is the key to the company's operational growth and goal achievement. This kind of commitment is a kind of trust (Allen and Grisaffe 2001). Because loyalty is not created out of thin air, if employees do not have sufficient work efficiency to assist the company in achieving its operational goals, the company is unwilling to pay them satisfactory salary for a long time. On the other hand, in order to increase efficiency, the company needs to require employees to improve their work performance or adjust the working environment. As a result, to fulfill the expectation of peers and supervisors, employees work in a state of tension and under increasing pressure. However, to improve the situation, the company should maintain its trust in employees, delegate more power to employees, and support their career development. Therefore, it is inferred that if employees are fully empowered during work and feel that their career development are supported by the company, their job satisfaction will be improved. Therefore, Hypotheses 8-9 is put forward: levels of delegation ( $\mathrm{H} 8)$ and career development $(\mathrm{H} 9)$ positively and significantly affect job satisfaction. Examining the human resource system of hotels from the perspective of employees would help researchers understand the current status of the corporate human resource training system and further explore the implementation of corporate social responsibility (Friedman 2007; Huemann et al. 2007; Marlow 2006; Noe et al. 2003; Wu et al. 2010).

\section{Methods}

\section{Research structure}

The epidemic has impacted the tourism industry as well as the hotel industry, and it has caused great harm to the hotel industry along the coast of China. Tourism development requires sufficient manpower. According to the literature, the hotel industry currently has a huge manpower shortage and insufficient recruitment channels. Therefore, industry-academia cooperation projects have been used to cultivate talents and supplement manpower (Leonchuk and Gray 2019; Ministry of Education of China 2020). However, studies found that due to changes in tourism patterns, high labor-intensity (Foo et al. 2020a), wage gap (Yunfei and Qin 2019) and other internal issues, coupled with external factors such as the raging COVID-9, the turnover rate is high, the employment willingness has declined, and manpower shortage has been caused. It can be seen that seeking to improve the problem of manpower shortage will be an urgent issue.

Studies have confirmed that there are methods for exploring employee satisfaction and loyalty (Kwon et al. 2010). Employee satisfaction can be understood by studying working environment, salary, organizational commitment and interpersonal relationships (Allen and Grisaffe 2001; Bushra et al. 2011; Smith et al. 1969; Yukongdi and Shrestha 2020), employee loyalty can be explored by studying the levels of delegation and career development (Abdullah et al. 2011; Farrukh et al. 2019; Reynolds 2019; Yao et al. 2019), and there is mutual influence between each other. This method helps to find out and enhance the social responsibility of island hotels and solve the problem of manpower shortage, as shown in Fig. 1. 


\section{Research hypothesis}

As illustrated in the research structure, the hypotheses of the research are as follows:

$\mathrm{H} 1$ Hotel trainees have the same understanding of job content satisfaction.

$\mathrm{H} 2$ Hotel trainees have the same recognition of corporate loyalty.

H3 There is a significant relationship between job satisfaction and corporate loyalty.

$\mathrm{H} 4$ There is a significant relationship between working environment and corporate loyalty.

H5 There is a significant relationship between salary and benefits and corporate loyalty.

H6 The relationship between corporate culture and corporate loyalty is significant.

$\mathrm{H} 7$ There is a significant correlation between interpersonal relationship and job satisfaction.

H8 There is a significant correlation between Degree of work authorization and job satisfaction.

H9 There is a significant correlation between job promotion elasticity and job satisfaction.

\section{Subjects}

In particular, the pleasant climate in Fujian Province has attracted a large number of international tourists to spend money there for years, resulting in significant growth in the number of Coastal Region Hotels and a boom in tourism development (Matzler and Renzl 2006). However, the slow start of China's tourism development and the speed of manpower training cannot cope with the demand, and the hotel manpower turnover rate is high and the willingness to stay is low (Hotel Industry Research Center, Zhongrui Hotel Management College 2019; Noe et al. 2003), which shows that the internal social responsibility system and implementation effectiveness of hotel enterprises are flawed. Therefore, hotel enterprises are currently cooperating with schools to promote university student hotel talent training programs, attempting to bring in fresh university graduates to enter the workplace early and train them as talents to compensate for the shortage of talent, which has become one of the main sources of hotel primary manpower. The effectiveness of implementing this policy needs time to be verified. In order to understand the degree of decision implementation and find out the deficiencies, the most realistic way is to examine the perceptions of the employees in the field (Ap and Crompton 1998; Widaningsih et al. 2020). Therefore, in this study, a questionnaire survey was used to select the participants by intentional sampling method, and a snowball method was used to obtain more samples from the current hotel trainees in Fujian Province. A total of 300 questionnaires were collected and 20 invalid questionnaires were excluded, resulting in a total of 280 valid questionnaires and a recovery rate of $93.3 \%$. The data were then coded, and the valid questionnaire data were documented with the SPSS 22.0 statistical software and analyzed for demographic variables, job satisfaction, and loyalty of the hotel trainees using statistical validation. Then, AMOS 20.0 software was used to analyze the relationship between the variables and validate the research model, and Pearson Correlation was used to analyze the relationship between job satisfaction and corporate loyalty. Focused interviews were then used to obtain the opinions of experts and scholars with backgrounds in hotel operations, working experiences, or professions, and the paper was constructed following a sequence of summarization, organization, and analysis (Gursoy et al. 2002). Finally, the multivariate verification analysis 
method was used to integrate the information of different research subjects, research theories and methods, and multiple viewpoints to verify multiple data and compare the research results (Gursoy et al. 2002; Janesick 2000; Strauss and Corbin 1998) in order to obtain accurate knowledge and meaning.

\section{Study procedure and instruments}

From the perspective of hotel trainees, this article examines the hotel talent training system in terms of job satisfaction and loyalty perceptions, in order to understand the effectiveness of hotel enterprises in promoting social responsibility and to analyze the key factors for the sustainable development of hotel enterprises. The research mainly analyzes the results of employee corporate loyalty and job satisfaction in the current COVID-19 infectious environment. It is believed that even in the current pandemic exploring the relationship between job satisfaction and employee loyalty can be helpful for finding solutions to the manpower shortage in China's hotel industry, according to the relevant research results (Abdullah et al. 2011; Farrukh et al. 2019; Reynolds 2019; Yao et al. 2019), inference and analysis of company loyalty (Allen and Grisaffe 2001; Bushra et al. 2011; Gupta and Mikkilineni 2018; Smith et al. 1969) and job satisfaction (Farrukh et al. 2019; Foster et al. 2008; Friedman 2007; Huemann et al. 2007; Marlow 2006; Noe et al. 2003; Reynolds 2019; Wu et al. 2010). The questionnaire can be divided into three parts: background variables, job satisfaction, and company loyalty. The background variables (Reynolds 2019) are related to gender, department, and geographic location of workplace. A total of 3 relevant questions are posed, and their question numbers are 1-3. Job satisfaction referencing to (Allen and Grisaffe 2001; Bushra et al. 2011; Smith et al. 1969; Yee et al. 2010) is divided into four dimensions. A total of 17 relevant questions are posed, and the question numbers are 4-20. Company loyalty referencing (Abdullah et al. 2011; Farrukh et al. 2019; Reynolds 2019; Yao et al. 2019) is divided into two dimensions, power control and career development, a total of 6 questions posed. There are 26 questions in total, as shown in Figs. 2 and 3.

Demographic variables include gender (male, female), work department (front desk, catering, guest room, kitchen, other), work location (local employment internship, non-indigenous employment internship). The 5-point Likert scale was used, ranging from strongly agree, agree, undecided, disagree to strongly disagree, with 1-5 points respectively. Job satisfaction referencing to (Allen and Grisaffe 2001; Bushra et al. 2011; Smith et al. 1969; Yee et al. 2010) is divided into four dimensions, work environment, salary, organizational commitment and interpersonal relationship. The company loyalty (Abdullah et al. 2011; Farrukh et al. 2019; Reynolds 2019; Yao et al. 2019) is divided into two dimensions, levels of delegation and development opportunities, as shown in Table 1.

\section{Information processing and analysis}

It is a corporate social responsibility to stabilize the development of enterprises and communities and to provide employment opportunities for residents to improve their quality of life in a mutually beneficial way (Wu 2017), which is also a major concern for society and the public (Uduji and Okolo-Obasi 2019). It is a new concept to explore the work system from the perspective of employees to understand whether the company can provide perfect job security for employees and fulfill its social responsibility. Innovative research methods need to be combined with new theories, based on grounded theory, using mixed research methods, first using quantitative research methods to get the opinions of the majority (Galli et al. 2020; Ochieng 2009), and then using qualitative research to obtain more profound, More subtle insights (Berry et al. 2019) can make up for the theoretical shortcomings (Cypress 2018). The first step was to eliminate the invalid questionnaires from the returned 
responses, code the valid questionnaire data, and use the SPSS 22.0 statistical software to document the data. The relationship between job satisfaction and corporate loyalty was analyzed by Pearson Correlation. Focused interviews were then used to ask experts and scholars with hotel operations, work, or professional backgrounds about their opinions on the analysis results, and the research paper was constructed by applying the sequence of induction, organization, and analysis (Gursoy et al. 2002). Finally, the multivariate check analysis method was used to combine the information of different research subjects, research theories and methods, and multiple viewpoints to verify multiple data and compare the research results (Gursoy et al. 2002; Janesick 2000; Strauss and Corbin 1998) to obtain accurate knowledge and meaning.

According to the analysis of the data from the 280 questionnaires, the majority of the respondents are female, accounting for $59.1 \%$, and $40.9 \%$ of them are male. The largest proportion of the respondents worked in catering department as interns, accounting for $30.9 \%, 25.5 \%$ of them worked at front desk as interns, $12.3 \%$ in guest room department, $4.5 \%$ in kitchen, and others $26.8 \%$. Most interns have selected hotels close to their places of residence, accounting for $60 \%$, and $40 \%$ of the interns worked at hotels far away from their places of residence.

\section{Offending estimate}

As shown in Table 2, we can see that the error variance of this research model is 0.02 to 0.05 , and the standardized regression coefficient is 0.75 to 0.96 , none of which exceeds 0.96 . Then the relevant testing was carried out to determine whether there is a negative error variance or the standardized regression coefficient exceeds or is too close to the standard of 1 (Bagozzi and $\mathrm{Yi}$ 1988) [76]. Therefore, this means that there is no offending estimate situation about the results, and the overall model can be tested for goodness of fit.

\section{Measurement mode analysis}

Verification of convergent validity

In this study, the convergent validity of the measurement model was tested using the standardized path coefficient, the average variance extracted and the composite reliability. Generally speaking, the composite reliability needs to be greater than 0.60 , and the average variance extracted needs to be greater than 0.50 [76]. As shown in Table 3, as for job satisfaction, the values related to working environment dimension are between 0.76 and 0.90 , the values related to the salary and benefits dimension are between 0.53 and 0.75 , the values related to company culture dimension are between 0.66 and 0.89 , and values related to interpersonal relationship dimension is between 0.89 and 0.90 . As for employee loyalty, the values related to the level of delegation dimension are between 0.80 and 0.83 , the values related to development opportunities dimension are between 0.83 and 0.84 . The composite reliability scores of the four potential variables of job satisfaction, working environment, salary and benefits, company culture, and interpersonal relationships is $0.82,0.65,0.79$, and 0.86 respectively, and the composite reliability scores of the two potential variables of loyalty, levels of delegation and development opportunities, are 0.80 and 0.83 respectively. The composite reliability scores are all greater than 0.60 and the average variance extracted is greater than 0.50 , indicating that the model is of good inherent quality and convergent validity.

Structural model analysis 
For structural model analysis of this study, $\chi 2$ test, the ratio of $\chi 2$ to degrees of freedom, GFI, AGFI, RMSEA, CFI, and PCFI are used to carried out relevant analyses (Bagozzi and Yi 1988). After the revision of the job satisfaction scale model, GFI is 0.91 , AGFI is 0.87 , RMSEA is $0.07, \mathrm{CFI}$ is 0.97 , and PCFI is 0.74 . After the revision of the company loyalty scale model, GFI is 0.98 , AGFI is 0.94 , RMSEA is $0.07, \mathrm{CFI}$ is 0.97 , and PCFI is 0.74 . As shown in Table 4, all the fitness indicators meet the model fitting criteria, indicating that the results of this study are acceptable models with good convergent validity and discriminant validity.

\section{Research result}

Analysis on the current situation of interns job satisfaction and employee loyalty

The internal social responsibility of the company includes providing proper working conditions, planning and perfecting human resource management system (Friedman 2007), meeting the needs of actual operation and employees, improving employees' performance, achieving corporate profitability goals, and further providing employees with job and livelihood security (Marlow 2006). Job satisfaction is one of the effective factors that influence the content of employees' work. If the content of work, environment and gains can be balanced, job satisfaction will be higher (Liu et al. 2019; Seashore and Taber 2001). Based on the literature, the researchers divided job satisfaction into four dimensions, working environment, salary and benefits, company culture, and interpersonal relationships, and there were 17 relevant questions in total. It was found that the respondents attach importance to salary and benefits (2.9), care least about company culture (2.69), pay more attention to disciplinary rules (2.75), benefits package (2.91), job rotation (2.72), and interaction with colleagues and communication with boss (2.73), and care less about career planning (2.65), peer cooperation and collaboration (2.70), work facilities (2.73), and compensation system (2.82), as shown in Table 5.

If employees feel intense loyalty to the company, this will promote the interaction between supervisors and employees and the company's trust in and support for subordinates and employees, and further boost the overall operation of the company (Bushra et al. 2011; Farrukh et al. 2019). This will facilitate sustainable business operations and meet the basic costs of maintaining internal corporate social responsibility. According to the literature, employee loyalty is divided into empowerment degree and development opportunities. The analysis result shows that they attach more importance to the latter (2.86) and care less about the former (2.72). They also expect to obtain the delegation of authority to solve the problem (2.88), get development opportunities after the internship (2.88), and care less about the right to work (2.68) and personnel changes (2.84), as shown in Table 6.

\section{Correlation analysis of interns job satisfaction and employee loyalty}

High job satisfaction can inspire the loyalty of employees. Employees with loyalty to the company work efficiently. They can be valued by the company, and then get rewards, and then increase satisfaction again (Bushra et al. 2011; Farrukh et al. 2019; Foster et al. 2008; Gursoy et al. 2002). Thus, by increasing employee job satisfaction and corporate recognition, job performance can be promoted which helps hotels to achieve their operational goals (Marlow 2006) and facilitates employees to obtain corporate employment commitments (Wu et al. 2010), so that the internal social responsibility of hotel companies can be fulfilled. Therefore, Hypothesis 3 is proposed. According to the analysis results, job satisfaction and company loyalty are highly correlated $(0.895$, $\mathrm{p}<0.01)$, confirming that Hypothesis 3 is true. In addition, the better the working environment is, the higher the job loyalty (0.862).

Page $12 / 29$ 
Job satisfaction can be explored from the perspectives of working environment, salary and welfare, corporate culture and interpersonal relationships, so hypothesis 4-7 is proposed. It can be seen that working environment, salary and benefits, company culture, and interpersonal relationships of job satisfaction have a significant impact on loyalty $(P<0.01)$, confirming that Hypothesis $2-6$ is valid. It was also found that the better the planning of workplace facilities $(0.805)$, staff canteen $(0.639)$, job rotation $(0.772)$, and cooperation and collaboration between colleagues (0.785), the stronger the interns' loyalty to the company, as shown in Fig. 4.

Work performance is the key to the growth of business operations, and it is also the employee's commitment to the company. It is also a kind of trust employers put in employees (Allen and Grisaffe 2001). Strong loyalty urges employees to actively complete tasks and improve effectiveness. Therefore, Hypothesis 3 is proposed. The analysis result shows that company loyalty and job satisfaction are significantly correlated $(0.895, p<0.01)$, which confirms Hypothesis 3. In addition, the higher the level of delegation is, the higher the job satisfaction (0.862).

Furthermore, company loyalty can be discussed from the perspectives of the level of delegation and development opportunities, and employees with different positions have different opinions, so Hypothesis 8-9 is proposed. The analysis result shows that the level of delegation and development are significantly correlated with job satisfaction $(P<0.01)$, confirming Hypothesis $8-9$. In addition, it was found that interns who could choose their own work methods $(0.895)$ to perform tasks had greater job satisfaction and more development opportunities (0.876) after the internship, as shown in Fig. 5.

\section{Discussion}

Discussing the effectiveness of corporate social responsibility from employees' satisfaction with hotel work When companies fulfill their internal social responsibility, employees can obtain stable salary and living security, a more comfortable working environment (2.81), and interact with a quality team (2.73) to develop their potential, they will expect to be promoted (2.72), become more enthusiastic about their work, and receive more benefits (3.05). However, after investing a large amount of money in the construction of hardware facilities, there is an urgent need to make a profit and recover the cost of investment. Even though the tourism industry is highly profitable, hardware and equipment are not easily updated (2.73) and cannot keep up with the industry demand and consumption trend in time. In addition, most hotel jobs are labor-based (2.73), low-skilled, and highly substitutable (2.65). Unless individuals have sufficient professional skills and qualities (2.65), it is not easy for companies to raise the salary of hotel general staff (2.82). As a result, employees believe that even if the company provides hard-earned salaries to employees, it is the employer's internal social responsibility to satisfy the employees' work and living needs and to execute the labor contract obligations. Therefore, the employees believe that the hotel company's internal human resource management system still has room for improvement in terms of work facilities, salary system, employee training planning, and employment recruitment due to operational and cost considerations. Therefore, Hypothesis 1 is not valid.

The researchers believe that in a difficult economic environment, business operations are even more challenging. In order to survive the difficult times, the industry should provide perfect human resource management measures, fulfill internal social responsibilities, provide a safe and comfortable working environment for employees, and satisfy their work and living needs, in order to enhance employees' trust in the labor contract and more

Page 13/29 
proactively help the company achieve its operational goals. Therefore, if the company can improve the talent training system, adjust the benefits, establish a rotation mechanism for work content, and establish a clear system of rewards and penalties, it can improve the inadequacy of the hotel talent training mechanism, maintain the staff's motivation, and fulfill the internal social responsibility of the company.

Discussion on the effectiveness of corporate social responsibility from the perspective of employee loyalty to hotel companies

Employees with high loyalty can be trusted by the company which enhances work effectiveness (Friedman 2007). However, in China, hotel employees have low salaries and high turnover rates (Yunfei and Qin 2019) and are insecure in their jobs. Under the pressure of life's hardships, the general staff have developed aggressive personality traits, only care about getting stable income and liberal working conditions (2.76), always cultivate workplace competitiveness and look for better job opportunities (2.88), and do not pay attention to the role they play in the company at the moment and fulfill their job responsibilities. Furthermore, although companies are aware that if they fulfill their internal social responsibility, they can promote employee cohesion, improve work effectiveness, and achieve operational goals (Friedman 2007; Marlow 2006), and that employee performance is a key factor in operational effectiveness (Noe et al. 2003; Wu 2017), the current human resource management measures of Chinese hoteliers are old-fashioned, and the employment treatment is conservative and fails to meet employment expectations, which leads to more distrust of employees. The reluctance to adjust and delegate work authority (2.68), improve the promotion system for the general staff (2.84) and fulfill internal corporate social responsibility invariably creates a confrontation between enterprises and employees, forming a vicious cycle. Therefore, hypothesis 2 is not valid.

Therefore, if the hotel can establish proper appointment measures for human resources, set clear rules of work and reward and punishment mechanisms, meet the needs of employees in work and life, and further promote the corporate culture and welfare system, it can further strengthen employees' trust in the company, stabilize their workplace attitudes and behaviors, and help improve their work performance so that the hotel can achieve its operational goals and be willing to adhere to its internal social responsibility so as to achieve the goal of coprosperity between the company and its employees.

Discussion on the sustainable development strategy of hotel companies from the relationship between job satisfaction and employee loyalty

The present study concluded that the implementation of internal social responsibility and the establishment of a good human resource management system in hotels can gain employees' recognition of the company, increase team spirit, promote work performance, and help the company maintain its competitive advantage (Friedman 2007; Marlow 2006; Wu 2017). It can be seen that a good working atmosphere and a comfortable working environment can promote employees' identification with the company, increase their enthusiasm for work, improve efficiency, help the company achieve its operational goals, create more profitable conditions, and increase the willingness of the owners to maintain their internal social responsibility and to further improve HR management measures to reach hotel performance target and move towards the goal of sustainable management. Therefore, job satisfaction and corporate loyalty showed a significant correlation, and hypothesis 3 of this study is valid. 
Despite the fact that companies and employees are part of the same group, there are differences in their respective goals and expectations. While the business owner aims to make profits from its operations, the employees expect to obtain resources to feed themselves and improve their quality of life through the shelter of the business, and they work hard for their respective goals. Nevertheless, business operations still need to rely on the general workforce to maintain hotel operations and service needs (Yee et al. 2010). Therefore, creating a safe, comfortable, and highly interactive working environment for employees, providing additional working facilities and meals, and planning a comprehensive application system for workplace job rotation will be the key to enhance employees' loyalty to the hotel company. However, the strong self-awareness of the younger generation, the gap in generational values, and the low salary level of hotels in China in general (Yunfei and Qin 2019) make the workplace attitude and corporate identification of the newcomers in the current society quite different from those in the past. Without providing employees with an autonomous work style and planning a proper promotion system to make them satisfied, it would be impossible to convince them to stay in the hotel business. Therefore, there is a significant correlation between empowerment, advancement and job satisfaction, working environment, salary and benefits, corporate culture, and interpersonal relationship with corporate loyalty which confirms research hypothesis 4-9. The more complete the planning of workplace facilities and equipment, employee canteens, job transition mechanism, and cooperation and collaboration among colleagues, the higher the corporate loyalty. The more complete the work autonomy and promotion channel, the higher the job satisfaction.

Therefore, if Chinese hotel companies wish to move towards sustainable development goals and boost corporate performance, they must first improve workplace facilities and staff canteens, establish a sound promotion mechanism, create a harmonious and supportive workplace atmosphere, construct a reasonable work system, and raise salaries in order to gain employees' recognition of the hotel corporate culture and workplace.

While enterprises should fulfill their social responsibilities, employees themselves need to have correct awareness of workplace ethics and responsibilities. Although this is not the topic of this paper, after all, entrepreneurs and employees are two different roles. The owner is responsible for making profits and losses, paying costs, and providing salaries to employees (Androniceanu 2019; Singh and Misra 2021), while employees are responsible for providing personal labor and skills, and exchanging their time and wisdom for equivalent salaries to help hotels achieve their operational goals (Hotel Industry Research Center, Zhongrui Hotel Management College 2018; Leonchuk and Gray 2019; Ministry of Education of China 2020; Yunfei and Qin 2019). Therefore, the study concluded that it is reasonable for good talents to expect to be appreciated by the company for better treatment and improved quality of life, but they also need to do their job well in order to be able to negotiate with the company. Successful business owners need good talents to assist in business operations, and good talents depend on the establishment of sound internal social responsibility and continuous improvement of talent training and benefit measures in order to truly fulfill corporate social responsibility, improve corporate performance, and move toward sustainable business goals.

\section{Conclusions And Recommendations}

At present, hotel owners are unable to maintain staff commitment and establish a sound internal social responsibility system due to inadequate human resource training system and welfare benefits, unclear rotation mechanism and reward and punishment system. Therefore, by establishing proper human resource management measures, improving workplace facilities and staff meals, establishing a perfect promotion mechanism, creating a harmonious workplace environment, constructing a reasonable work system, increasing salaries, and 
strengthening the corporate culture and welfare system promotion mechanism, we can ensure a stable workplace attitude and behavior of employees, improve work performance, enhance corporate commitment, and help Coastal Region Hotels achieve their operational goals, improve performance, fulfill their corporate social responsibility, and move towards sustainable development.

\section{Suggestions for for hotel entrepreneurs}

The company needs to provide employees: 1 . Meet basic life needs. 2. Propose a stable work rotation mechanism. 3. Clarify the promotion path and work guide. 4. Give trust and assist in proficient business. In this way, the company can obtain the recognition of interns and fulfill its corporate social responsibility.

\section{Suggestions for hotel employees (new employees)}

Existing or new employees need to: 1. Self-improvement skills. 2. Increase professional knowledge. 3. Enhance workplace value. 4. Face up to your role in the hotel. The implementation of the above conditions will obtain more work resources and opportunities and gain the trust of the enterprise.

\section{Suggestions for government authorities}

The government needs to implement: 1. Need to listen to the opinions of labor and management. 2. Assist in obtaining consensus between labor and capital. 3. Put forward measures to stabilize industrial human resources. Only in this way can we urge business owners to fulfill their corporate social responsibilities, build a sound hotel industry operation and management mechanism, and stabilize the development of China's hotel industry.

\section{Research recommendations}

From the perspective of different rights relations, obtain their views on related issues, and use other analytical methods to confirm or discuss related issues to make up for research deficiencies.

\section{Declarations}

Ethics approval and consent to participate This research does not involve human trials, and the interviewees are conducting the investigation under the understanding of the research theme and full authorization, so there is no need for ethical approval. All interviewees agreed to authorize the provision of interview information.

Consent for publication The Author grants the Publisher the sole and exclusive license of the full copyright in the Contribution, which license the Publisher hereby accepts.

Availability of data and materials The case and research samples presented in the content of this research report shall be collected and sampled after approval.

Competing interests The authors declare that they have no competing interests.

Funding This research received no external funding.

Authors' contributions Each author's assistance to the article is: BWX: Conceptualization, Supervision. LHH: Conceptualization, Formal analysis, Investigation, Methodology, Writng-original draft, Writng-review \& edtion, 
Software, Validation. HCH: Writng-original draft, Project administration, Resources, Funding acquisition. CCC and PYL: Lnvestigation, Data curation, Resources. Every author has made significant contributions.

Acknowledgements We are grateful to all participating editors. They have made great contributions to this article. We are also grateful for assisting in investigating people, making the research complete and obtaining meaningful survey results and contributions.

\section{References}

1. Abdullah RB, Musa M, Zahari H, Rahman R, Khalid K (2011) The study of employee satisfaction and its effects towards loyalty in hotel industry in Klang Valley, Malaysia. Int J Bus Soc Sci 2:147-155

2. Agarwal P (2020) Shattered but smiling: Human resource management and the wellbeing of hotel employees during COVID-19. Hum Res Manag Rev 30:100778. https://doi.org/10.1016/j.hrmr.2020.100778

3. Allen NJ, Grisaffe DB (2001) Employee commitment to the organization and customer reactions: mapping the linkages. Hum Res Manag Rev 11:209-236. https://doi.org/10.1016/S1053-4822(00)00049-8

4. Al-Refaie A (2015) Effects of human resource management on hotel performance using structural equation modeling. Comp Hum Behav 43:293-303. https://doi.org/10.1016/j.chb.2014.11.016

5. Amin M, Aldakhil AM, Wu C, Rezaei S, Cobanoglu C (2017) The structural relationship between TQM, employee satisfaction and hotel performance. Int J Contemp Hosp Manag 29:1256-1278. https://doi.org/10.1108/IJCHM-11-2015-0659

6. Androniceanu A (2019) Social responsibility, an essential strategic option for a sustainable development in the field of bio-economy. Amfiteatru Econom 21:503-519

7. Ap J, Crompton JL (1998) Developing and testing a tourism impact scale. J Travel Res 37:120-130. https://doi.org/10.1177/004728759803700203

8. Awad TA, Alhashemi SE (2012) Assessing the effect of interpersonal communications on employees' commitment and satisfaction. Int J Islam Middle East Finance Manag 5:134-156. https://doi.org/10.1108/17538391211233425

9. Bagozzi RP, Yi Y (1988) On the evaluation of structural equation models. J Acad Market Sci 16:74-94

10. Baum T, Hai NTT (2020) Hospitality, tourism, human rights and the impact of COVID-19. Int J Hosp Manag 3:2397-2407

11. Berry N, Lobban F, Bucci S (2019) A qualitative exploration of service user views about using digital health interventions for self-management in severe mental health problems. BMC Psych 19:35. https://doi.org/10.1186/s12888-018-1979-1

12. Body A, Hogg E (2019) What mattered ten years on? Young people's reflections on their involvement with a charitable youth participation project. J Youth Stud 22:171-186.

https://doi.org/10.1080/13676261.2018.1492101

13. Bushra F, Ahmad U, Naveed A (2011) Effect of transformational leadership on employees' job satisfaction and organizational commitment in banking sector of Lahore (Pakistan). Int J Bus Soc Sci 2:261-267

14. Čančer V, Šarotar Žižek S (2017) A multiple-criteria approach to human resource management assessment in organizations with respect to industry. Kybernetes 46:419-432. https://doi.org/10.1108/K-09-2016-0236

15. Chi XX, Chi XL, Liang QL (2016). Strategic analysis of corporate social responsibility. Manag Rev 35:21-45 
16. Cumbey DA, Alexander JW (1998). The relationship of job satisfaction with organizational variables in public health nursing. J Nurs Admin 28:39-46

17. Cypress B (2018) Qualitative research methods: a phenomenological focus. Dimens Crit Care Nurs 37:302309. https://doi.org/10.1097/DCC.0000000000000322

18. Dube K, Nhamo G, Chikodzi D (2021) COVID-19 cripples global restaurant and hospitality industry. Curr Issues Tour 24:1487-1490. https://doi.org/10.1080/13683500.2020.1773416

19. Farrukh M, Alzubi Y, Shahzad IA, Waheed A, Kanwal N (2017) Entrepreneurial intentions: the role of family factors, personality traits and self-efficacy. World J Entrep Manag Sustain Dev 13:303-317. https://doi.org/10.1108/WJEMSD-03-2017-0018

20. Farrukh M, Kalimuthuan R, Farrukh S (2019) Impact of Job satisfaction and mutual trust on employee loyalty in Saudi hospitality industry: a mediating analysis of leader support. Int J Bus Psychol 1:30-52

21. Foo LP, Chin MY, Tan KL, Phuah KT (2020a) The impact of COVID-19 on tourism industry in Malaysia. Curr Issues Tour. https://doi.org/10.1080/13683500.2020.1777951

22. Foo LP, Chin MY, Tan KL, Phuah KT (2020b) An initial assessment of economic impacts and operational challenges for the tourism \& hospitality industry due to COVID-19. Curr Issues Tour. https://doi.org/10.1080/13683500.2020.1777951

23. Foster C, Whysall P, Harris L (2008) Employee loyalty: an exploration of staff commitment levels towards retailing, the retailer and the store. Int Rev Retail Distrib Consum Res 18:423-435. https://doi.org/10.1080/09593960802299494

24. Foy T, Dwyer RJ, Nafarrete R, Hammoud MSS, Rockett P (2019) Managing job performance, social support and work-life conflict to reduce workplace stress. Int J Prod Perform Manag 68:1018-1041

25. Friedman BA (2007) Globalization implications for human resource management roles. Empl Responsib Rights J 19:157-171

26. Galli A, Iha K, Pires SM et al (2020). Assessing the ecological footprint and biocapacity of Portuguese cities: critical results for environmental awareness and local management. Cities 96:102442. https://doi.org/10.1016/j.cities.2019.102442

27. Gao ZJ (2007) Research on the effect of internship in hotel management. Master's Thesis, Dongbei University of Finance and Economics

28. Gupta M, Mikkilineni S (2018) Spirituality and employee engagement at work. In: The Palgrave handbook of workplace spirituality and fulfillment, pp 681-695

29. Gursoy D, Jurowski C, Uysal M (2002) Resident attitudes: a structural modeling approach. Ann Tour Res 20:79-105. https://doi.org/10.1016/S0160-7383(01)00028-7Get

30. Gursoy D, Maier TA, Chi CG (2008) Generational differences: an examination of work values and generational gaps in the hospitality workforce. Int J Hosp Manag 27:448-458.

https://doi.org/10.1016/j.ijhm.2007.11.002

31. Hao F, Xiao Q, Chon K (2020) COVID-19 and China's hotel industry: impacts, a disaster management framework, and post-pandemic agenda. Int J Hosp Manag 90:102636.

https://doi.org/10.1016/j.jihm.2020.102636

32. Hotel Industry Research Center, Zhongrui Hotel Management College (2018) Survey report on the status quo of human resources in Chinese hotels. 2018 Hotel Review Talent Development Forum, Beijing 
33. Hotel Industry Research Center, Zhongrui Hotel Management College (2019) Survey report on the status quo of human resources in Chinese hotels. 2019 Hotel Review Talent Development Forum, Beijing

34. Hsu CH, Lin HH, Wang CC, Jhang S (2020) How to Defend COVID-19 in Taiwan? Talk about people's disease awareness, attitudes, behaviors and the impact of physical and mental health. Int J Environ Res Public Health 17:4694. https://doi.org/10.3390/ijerph17134694

35. Huemann M, Keegan A, Turner JR (2007) Human resource management in the project-oriented company: a review. Int J Project Manag 25:315-323. https://doi.org/10.1016/j.ijproman.2006.10.001

36. Janesick VJ (2000) The choreography of qualitative research design: minuets, improvisations, and crystallization. In: Denzin NK, Lincoln YS (eds.) Handbook of qualitative research. Sage, Thousand Oak, CA, pp 379-399

37. Jiang Y, Wen J (2020) Effects of COVID-19 on hotel marketing and management: a perspective article. Int J Contemp Hosp Manag 32:2563-2573. doi:10.1108/IJCHM-03-2020-0237

38. Kwon K, Bae J, Lawler JJ (2010) High commitment HR practices and top performers. Manag Int Rev 50:5780. https://doi.org/10.1007/s11575-009-0023-6

39. Larivière B, Keiningham TL, Aksoy L, Yalçin A, MORGESON FV III, Mithas S (2016) Modeling heterogeneity in the satisfaction, loyalty intention, and shareholder value linkage: a cross-industry analysis at the customer and firm levels. J Market Res 53:91-109. https://doi.org/10.1509/jmr.12.0143

40. Leonchuk O, Gray DO (2019) Scientific and technological (human) social capital formation and IndustryUniversity Cooperative Research Centers: a quasi-experimental evaluation of graduate student outcomes. J Technol Transf 44:1638-1664. https://doi.org/10.1007/s10961-017-9613-9

41. Li C (2019a) Research on the influencing factors of work stress of grassroots female employees in high-star hotels. Master's Thesis, Shenyang Normal University

42. Li F (2019b) On tourism diplomacy: levels, attributes and functions. Tour Tribune 34:113-124. https://doi.org/10.19765/j.cnki.1002-5006.2019.03.014

43. Liu J, Zhu B, Wu J, Mao Y (2019) Job satisfaction, work stress, and turnover intentions among rural health workers: a cross-sectional study in 11 western provinces of China. BMC Fam Pract 20:9. https://doi.org/10.1186/s12875-019-0904-0

44. Marlow S (2006) Human resource management in smaller firms: a contradiction in terms? Hum Res Manag Rev 16:467-477. https://doi.org/10.1016/j.hrmr.2006.08.004

45. Matzler K, Renzl B (2006) The relationship between interpersonal trust, employee satisfaction, and employee loyalty. Total Qual Manag Bus Excell 17:1261-1271. https://doi.org/10.1080/14783360600753653

46. Ministry of Culture and Tourism of the People's Republic of China (2018) Statistical bulletin of national starrated hotels in the first quarter of 2018. http://zwgk. mct.

gov.cn/auto255/201808/t20180820_834316.html?keywords=2018.08.20/2019.5.23. Accessed 30 March 2020

47. Ministry of Education of China (2020) Number of students of formal education by type and level. https://web.archive.org/web/20190404000813/http://www.moe.edu. cn/s78/A03/moe_560/jytjsj_2017/qg/201808/t20180808_344698.html. Accessed 05 September 2020

48. Nishii LH, Lepak DP, Schneider B (2008) Employee attributions of the "why" of HR practices: their effects on employee attitudes and behaviors, and customer satisfaction. Person Psychol 61:503-545. 
https://doi.org/10.1111/j.1744-6570.2008.00121.x

49. Noe H, Hollenbeck J, Gerhart B (2003) Wright. human resource management, international edition. The Mac Graw-Hill Companies, New York

50. Ochieng PA (2009) An analysis of the strengths and limitation of qualitative and quantitative research paradigms. Problems Educ 21st Cent 13:13-18

51. Parker LD (2020) The COVID-19 office in transition: cost, efficiency and the social responsibility business case. Account Audit Accountab J 33:1943-1967. doi:10.1108/AAAJ-06-2020-4609

52. Qiu XH (2008) Research on the development stage of tourism industry after China's reform and opening up. Master Thesis, Chiao Tung University

53. Reynolds C (2019) Back to the roots. The effects of personality traits and personal values on participation in civic groups. PhD Thesis

54. Sabuhari R, Sudiro A, Irawanto D, Rahayu M (2020) The effects of human resource flexibility, employee competency, organizational culture adaptation and job satisfaction on employee performance. Manag Sci Lett 10:1775-1786. https://doi.org/10.5267/j.msl.2020.1.001

55. Said NM, Hamir N, Fadzil H, Hakim FA, Sulaiman S, Yunus NM (2020) The effect of employees satisfaction towards loyalty in hotel industry: compensation, rewards, job security and working environment. ESTEEM J Soc Sci Hum 4:75-82

56. Seashore SE, Taber TD (2001) Job satisfaction and their correlation. Am Behav Sci 18:346

57. Shanock LR, Eisenberger R, Heggestad ED et al (2019) Treating employees well: the value of organizational support theory in human resource management. Psychol-Manag J 22:168-191. https://doi.org/10.1037/mgr0000088

58. Shenzhen Qianzhan Information Co., Ltd (2020) Market analysis of the global and Chinese hotel industry in 2020: the penetration rate of chain hotels continues to increase. The hotel supply is growing. https://bg.qianzhan.com/trends/detail/506/201229-4752dd66.html. Accessed 12 February 2021

59. Singh K, Misra M (2021) Linking Corporate Social Responsibility (CSR) and organizational performance: the moderating effect of corporate reputation. Eur Res Manag Bus Econom 27:100139.

https://doi.org/10.1016/j.iedeen.2020.100139

60. Smith PC, Kendall LM, Hulin CL (1969) The measurement of satisfaction in work and retirement: a strategy for the study of attitudes. Rand Mcnally

61. Strauss AL, Corbin J (1998) Basics of qualitative research: grounded theory procedures and techniques, 2nd edn. Sage, Thousand Oaks

62. Tang WH (2019) The overall contribution of the mainland's tourism industry in 2018 accounted for $11.04 \%$ of GDP. https://www.ttnmedia.com. Accessed 04 September 2020

63. Tan KL, Sim PL, Goh FQ, Leong CM, Ting H (2020) Overwork and overtime on turnover intention in non-luxury hotels: do incentives matter? J Hosp Tour Insights 3:397-414. https://doi.org/10.1108/JHTI-09-2019-0104

64. Uduji IJ, Okolo-Obasi EN (2019) Corporate social responsibility in Nigeria and rural youths in sustainable traditional industries livelihood in oil producing communities. J Int Dev 31:658-678. https://doi.org/10.1002/jid.3432

65. Wang C, Hu R, Zhang TC (2020) Corporate social responsibility in international hotel chains and its effects on local employees: Scale development and empirical testing in China. Int J Hosp Manag 90:102598. 
https://doi.org/10.1016/j.ijhm.2020.102598

66. Widaningsih, TT, Diana R, Rahayunianto A (2020). Community based cultural tourism development Setu Babakan, Jakarta. J Environ Manag Tour 11:486-495. https://doi.org/10.14505/jemt.v11.2(42).26

67. Wong AKF, Kim SS (2020) Development and validation of standard hotel corporate social responsibility (CSR) scale from the employee perspective. Int J Hosp Manag 87:102507.

https://doi.org/10.1016/j.ijhm.2020.102507

68. Wu BE, Huang LZ, Huang JQ, Wen JF, Liao WZ, Han ZX (2010) The third edition of human resource management theory and practice. Huatai Cultural Enterprise, Taipei

69. Wu CF (2017) An investigation of multilevel relationship between high-commitment HRM and work outcomes: the mediating effect of psychological ownership and moderating effect of locus of control. Master's Thesis, Draduate Institute of Human Resources and and eLearning Technology, National Tsing Hua University

70. Yao T, Qiu Q, Wei Y (2019) Retaining hotel employees as internal customers: effect of organizational commitment on attitudinal and behavioral loyalty of employees. Int J Hosp Manag 76:1-18. https://doi.org/10.1016/j.ijhm.2018.03.018

71. Yee R, Yeung A, Cheng T (2010) An empirical study of employee loyalty, service quality and firm performance in the service industry. Int J Prod Econom 124:109-120. https://doi.org/10.1016/j.ijpe.2009.10.015

72. Yukongdi V, Shrestha $P$ (2020) The influence of affective commitment, job satisfaction and job stress on turnover intention: a study of Nepalese bank employees. Rev Integr Bus Econom Res 9:88-98

73. Yunfei P, Qin D (2019) Research on the organizational restructuring of local colleges in the new era. Modern Educ Manag 12:43-51. https://doi.org/1674-5485(2019) 12-0043-19

\section{Tables}


Table 1

Questionnaire about job satisfaction and company loyalty

\begin{tabular}{|c|c|c|c|}
\hline \multicolumn{2}{|c|}{ Main part of the questionnaire } & Content & Numbering \\
\hline \multicolumn{2}{|c|}{ Background information } & Gender, age, education level & $1-3$ \\
\hline \multirow[t]{4}{*}{$\begin{array}{l}\text { Job } \\
\text { satisfaction }\end{array}$} & $\begin{array}{l}\text { Working } \\
\text { environment }\end{array}$ & $\begin{array}{l}\text { C1 facilities and equipment satisfy me } \\
\text { C2 working atmosphere satisfied me } \\
\text { C3 reward and punishment system pleases me }\end{array}$ & $4-6$ \\
\hline & Salary and benefits & $\begin{array}{l}\text { D1 salary system pleases me } \\
\text { D2 internship income satisfied me } \\
\text { D3 benefits plan satisfied me } \\
\text { D4 staff dormitory satisfied me } \\
\text { D5 staff canteen satisfied me } \\
\text { D6 bonus/reward system pleases me }\end{array}$ & $7-12$ \\
\hline & Company culture & $\begin{array}{l}\text { E1 corporate development philosophy pleases me } \\
\text { E2 employee career planning satisfied me } \\
\text { E3 job conversion mechanism pleases me }\end{array}$ & $13-15$ \\
\hline & $\begin{array}{l}\text { Interpersonal } \\
\text { relationship }\end{array}$ & $\begin{array}{l}\text { F1 colleagues get along well with me } \\
\text { I am satisfied with the results of cooperation and } \\
\text { collaboration between } \\
\text { F2 colleagues } \\
\text { I am satisfied with sharing work experience among } \\
\text { F3 colleagues } \\
\text { I am satisfied with the effectiveness of communication } \\
\text { between } \\
\text { F4 and my boss } \\
\text { F5 supervisor work scheduling and coordination satisfy } \\
\text { me }\end{array}$ & $16-20$ \\
\hline \multirow[t]{2}{*}{$\begin{array}{l}\text { Employee } \\
\text { loyalty }\end{array}$} & Power control & $\begin{array}{l}\text { G1 company is willing to fully authorize me to solve the } \\
\text { problem } \\
\text { G2 must be resolved in accordance with the company's } \\
\text { work guidelines } \\
\text { G3 can use its own methods to solve work problems }\end{array}$ & $21-23$ \\
\hline & Expansion capacity & $\begin{array}{l}\text { J1 has high development opportunities after taking } \\
\text { office } \\
\text { J2 promotion system is good } \\
\text { J3 has many on-the-job skills training opportunities }\end{array}$ & $24-26$ \\
\hline
\end{tabular}


Table 2

Job satisfaction and company loyalty scale offending estimate testing

\begin{tabular}{|c|c|c|c|}
\hline \multicolumn{4}{|c|}{ Job satisfaction scale offending estimate testing } \\
\hline Item code & & Standardized regression coefficient & Deviation variance \\
\hline \multirow[t]{3}{*}{ Working environment } & $\mathrm{C} 1$ & 0.91 & 0.03 \\
\hline & C 2 & 0.88 & 0.04 \\
\hline & C 3 & 0.77 & 0.05 \\
\hline \multirow[t]{6}{*}{ Salary and benefits } & D1 & 0.77 & 0.04 \\
\hline & D2 & 0.75 & 0.05 \\
\hline & D3 & 0.86 & 0.03 \\
\hline & D4 & 0.76 & 0.04 \\
\hline & D5 & 0.84 & 0.04 \\
\hline & D6 & 0.82 & 0.03 \\
\hline \multirow[t]{3}{*}{ Company culture } & E1 & 0.96 & 0.02 \\
\hline & E2 & 0.95 & 0.02 \\
\hline & E3 & 0.80 & 0.04 \\
\hline \multirow[t]{5}{*}{ Interpersonal relationship } & $\mathrm{F} 1$ & 0.94 & 0.02 \\
\hline & $\mathrm{F} 2$ & 0.94 & 0.02 \\
\hline & F3 & 0.95 & 0.02 \\
\hline & $\mathrm{F} 4$ & 0.89 & 0.03 \\
\hline & F5 & 0.88 & 0.04 \\
\hline \multicolumn{4}{|c|}{ Company loyalty scale offending estimate testing } \\
\hline \multirow[t]{3}{*}{ Power control } & G1 & 0.89 & 0.04 \\
\hline & $\mathrm{G} 2$ & 0.90 & 0.03 \\
\hline & G3 & 0.91 & 0.03 \\
\hline \multirow[t]{3}{*}{ Promotion flexibility } & $\mathrm{J} 1$ & 0.92 & 0.03 \\
\hline & $\mathrm{J} 2$ & 0.88 & 0.03 \\
\hline & J3 & 0.84 & 0.04 \\
\hline
\end{tabular}


Table 3

Scale reliability and average variance extracted

\begin{tabular}{|c|c|c|c|c|c|c|c|c|c|}
\hline \multicolumn{10}{|c|}{ Job satisfaction scale } \\
\hline Perspective & & Index & $\begin{array}{l}\text { Standardized } \\
\text { factor } \\
\text { loading }\end{array}$ & $\begin{array}{l}\text { Non- } \\
\text { standardized } \\
\text { factor } \\
\text { loading }\end{array}$ & S.E. & $\begin{array}{l}\text { C.R. } \\
(\mathrm{t}- \\
\text { value) }\end{array}$ & $P$ & SMC & C.R. \\
\hline \multirow{2}{*}{$\begin{array}{l}\text { Working } \\
\text { environment }\end{array}$} & $\mathrm{C} 1$ & 0.95 & 1.00 & & & & 0.90 & \multirow[t]{2}{*}{0.90} & \multirow[t]{2}{*}{0.82} \\
\hline & C3 & 0.87 & 0.97 & 0.05 & 20.15 & $\star \star \star ~$ & 0.76 & & \\
\hline \multirow{4}{*}{$\begin{array}{l}\text { Salary and } \\
\text { benefits }\end{array}$} & D1 & 0.73 & 1.00 & & & & 0.53 & \multirow[t]{4}{*}{0.88} & \multirow[t]{4}{*}{0.65} \\
\hline & $\begin{array}{l}\mathrm{D} \\
3\end{array}$ & 0.87 & 1.21 & 0.10 & 12.46 & 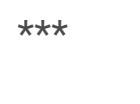 & 0.75 & & \\
\hline & $\begin{array}{l}\mathrm{D} \\
4\end{array}$ & 0.77 & 1.00 & 0.09 & 10.96 & $\star \star \star *$ & 0.60 & & \\
\hline & $\begin{array}{l}D \\
5\end{array}$ & 0.85 & 1.22 & 0.10 & 11.97 & 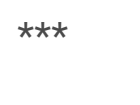 & 0.72 & & \\
\hline \multirow{3}{*}{$\begin{array}{l}\text { Company } \\
\text { culture }\end{array}$} & E1 & 0.92 & 1.00 & & & & 0.85 & \multirow[t]{3}{*}{0.92} & \multirow[t]{3}{*}{0.79} \\
\hline & $\begin{array}{l}E \\
2\end{array}$ & 0.94 & 1.00 & 0.04 & 24.84 & $\star \star \star ~$ & 0.89 & & \\
\hline & $\begin{array}{l}E \\
3\end{array}$ & 0.81 & 0.85 & 0.05 & 16.64 & 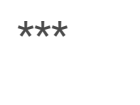 & 0.66 & & \\
\hline \multirow{4}{*}{$\begin{array}{l}\text { Interpersonal } \\
\text { relationship }\end{array}$} & $\mathrm{F} 1$ & 0.94 & 1.00 & & & & 0.89 & \multirow[t]{4}{*}{0.96} & \multirow[t]{4}{*}{0.86} \\
\hline & F2 & 0.95 & 0.96 & 0.03 & 29.59 & $\star \star \star$ & 0.90 & & \\
\hline & F3 & 0.95 & 0.99 & 0.03 & 29.97 & $\star \star \star ~$ & 0.91 & & \\
\hline & F4 & 0.87 & 0.84 & 0.04 & 21.49 & $\star \star \star *$ & 0.75 & & \\
\hline \multicolumn{10}{|c|}{ Employee Loyalty Scale } \\
\hline \multirow{3}{*}{$\begin{array}{l}\text { Power } \\
\text { control }\end{array}$} & G1 & 0.89 & 1.00 & & & & 0.80 & \multirow[t]{3}{*}{0.92} & \multirow[t]{3}{*}{0.80} \\
\hline & G2 & 0.89 & 0.94 & 0.05 & 19.39 & $\star \star \star ~$ & 0.80 & & \\
\hline & G3 & 0.91 & 0.93 & 0.05 & 20.22 & $\star \star \star ~$ & 0.83 & & \\
\hline \multirow{2}{*}{$\begin{array}{l}\text { Promotion } \\
\text { flexibility }\end{array}$} & J1 & 0.92 & 1.00 & & & & 0.84 & \multirow[t]{2}{*}{0.91} & \multirow[t]{2}{*}{0.83} \\
\hline & J2 & 0.91 & 1.00 & 0.05 & 18.72 & $\star \star \star$ & 0.83 & & \\
\hline
\end{tabular}


Table 4

The model fitting of Job satisfaction scale

\begin{tabular}{|lllll|}
\hline Job satisfaction scale & Tolerable range & $\begin{array}{l}\text { Modified } \\
\text { model }\end{array}$ & $\begin{array}{l}\text { Model fit } \\
\text { determination }\end{array}$ & Fit index \\
\hline Fit index & $\begin{array}{l}\text { The smaller the } \\
\text { better }\end{array}$ & 530.18 & 137.76 & \\
\hline $\begin{array}{l}\chi^{2} \text { (Chi-square) } \\
\text { ratio }\end{array}$ & $<3$ & 4.69 & 2.33 & Fit \\
\hline GFI & $>0.90$ & 0.79 & 0.91 & Fit \\
\hline AGFI & $>0.90$ & 0.71 & 0.87 & Fit \\
\hline RMSEA & $<0.08$ & 0.13 & 0.07 & Fit \\
\hline CFI & $>0.90$ & 0.90 & 0.97 & Fit \\
\hline PCFI & $>0.50$ & 0.75 & 0.74 & Fit \\
\hline Company loyalty scale & & & & Fit \\
\hline$\chi^{2}$ (Chi-square) & $\begin{array}{l}\text { The smaller the } \\
\text { better }\end{array}$ & 39.42 & 9.23 & Acceptable \\
\hline$\chi^{2}$ anddegree of freedom & $<3$ & 4.93 & 2.31 & Fit \\
\hline ratio & $>0.90$ & 0.93 & Fit \\
\hline GFI & $>0.90$ & 0.94 & 0.98 & Fit \\
\hline AGFI & $<0.08$ & 0.86 & 0.94 & Fit \\
\hline RMSEA & $>0.90$ & 0.13 & 0.07 & 0.99 \\
\hline CFI & $>0.50$ & 0.97 & 0.40 & Fit \\
\hline PCFI & 0.52 & & \\
\hline
\end{tabular}


Table 5

Analysis of current job satisfaction

\begin{tabular}{|c|c|c|c|c|}
\hline Facet & Index & M & $\boldsymbol{\sigma}$ & Ranking \\
\hline \multirow[t]{2}{*}{ Working environment $(\mathrm{M}=2.77)$} & Reward and punishment system & 2.75 & 1.066 & 1 \\
\hline & Workplace facilities and equipment & 2.73 & 1.157 & 2 \\
\hline \multirow[t]{4}{*}{ Salary and benefits $(M=2.90)$} & Benefits & 2.91 & 0.984 & 1 \\
\hline & staff dorm & 2.89 & 0.920 & 2 \\
\hline & staff cafeteria & 2.87 & 1.018 & 3 \\
\hline & Salary System & 2.82 & 0.975 & 4 \\
\hline \multirow[t]{3}{*}{ Company culture $(\mathrm{M}=2.69)$} & Job conversion mechanism & 2.72 & 0.989 & 1 \\
\hline & Development concept & 2.70 & 1.024 & 2 \\
\hline & Staff career planning & 2.65 & 0.998 & 3 \\
\hline \multirow{4}{*}{$\begin{array}{l}\text { Interpersonal relationship (M = } \\
2.70)\end{array}$} & Colleagues get along & 2.73 & 1.278 & 1 \\
\hline & Communication with boss & 2.73 & 1.170 & 2 \\
\hline & Sharing work experience among colleagues & 2.70 & 1.257 & 3 \\
\hline & $\begin{array}{l}\text { Cooperation and collaboration among } \\
\text { colleagues }\end{array}$ & 2.70 & 1.225 & 4 \\
\hline
\end{tabular}

Table 6

Analysis of the current situation of employee loyalty

\begin{tabular}{|lllll|}
\hline Facet & Index & M & $\boldsymbol{\sigma}$ & Ranking \\
\hline Power control $(\mathrm{M}=2.72)$ & $\begin{array}{l}\text { Solve the problem according to the authorization } \\
\text { guidelines }\end{array}$ & 2.76 & 1.082 & 1 \\
& $\begin{array}{l}\text { Choose your own working method } \\
\text { Right to match job position }\end{array}$ & 2.75 & 1.055 & 2 \\
\hline $\begin{array}{l}\text { Promotion flexibility }(\mathrm{M}= \\
2.86)\end{array}$ & Development opportunities after the internship & 2.68 & 1.154 & 3 \\
\cline { 2 - 5 } & Promotion system & 2.84 & 1.024 & 1 \\
\hline
\end{tabular}

\section{Figures}




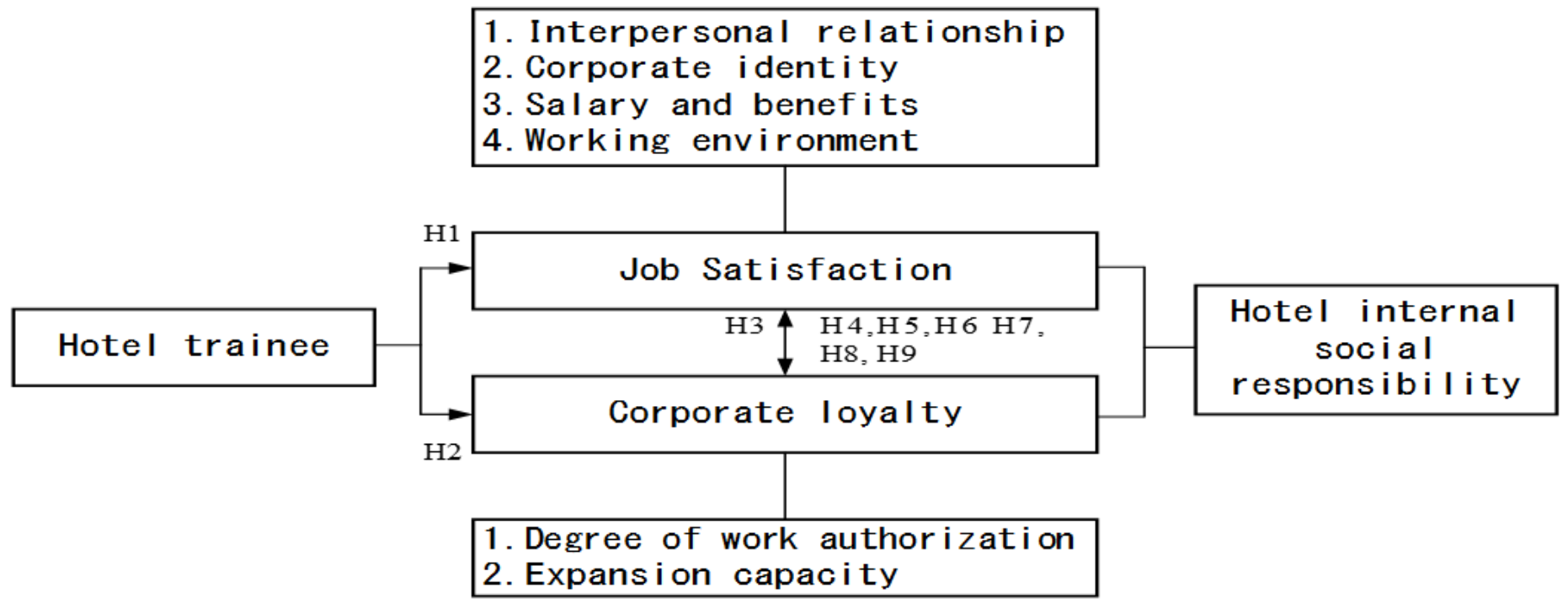

Figure 1

The research structure

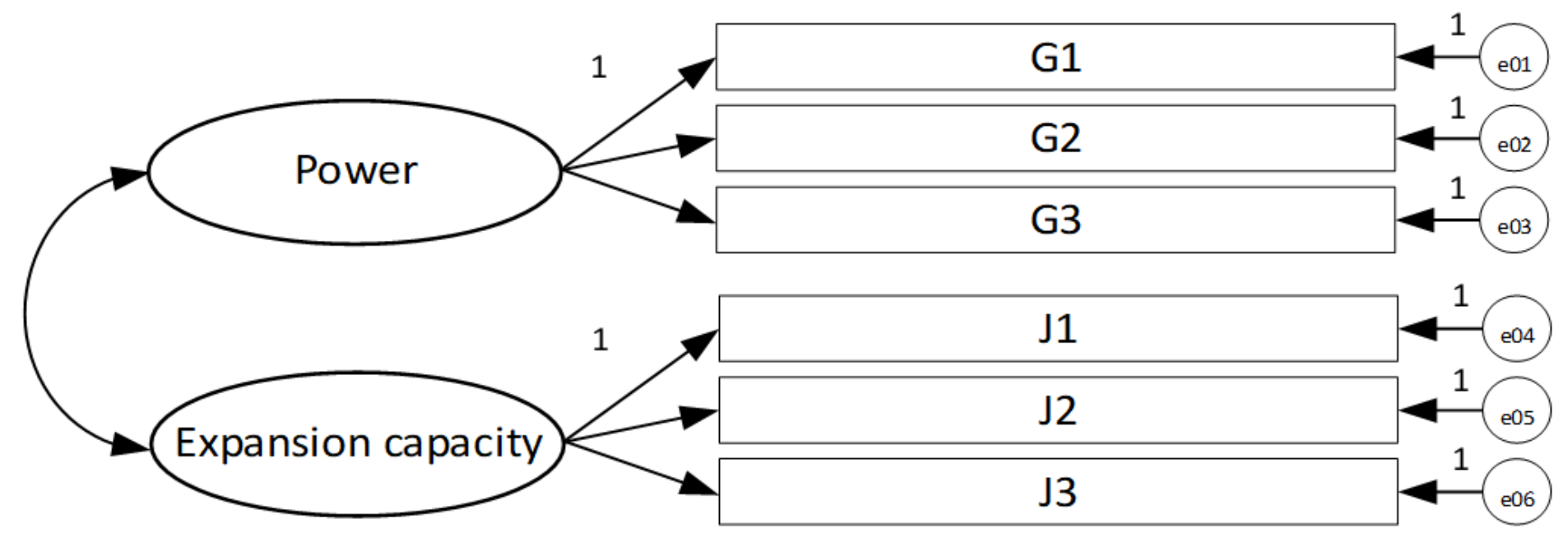

Figure 2

Confirmatory factor analysis framework for job satisfaction scale 


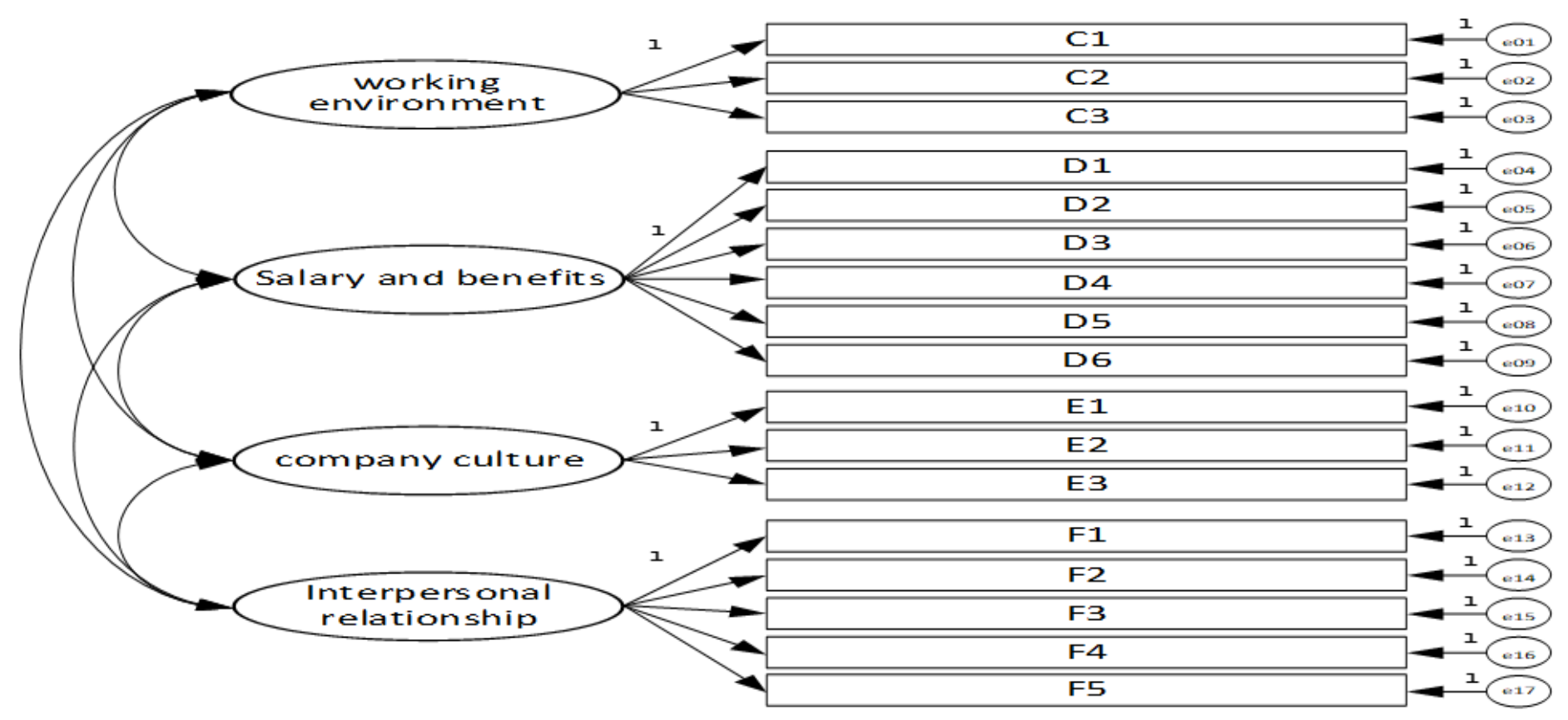

Figure 3

Confirmatory factor analysis framework for company loyalty scale

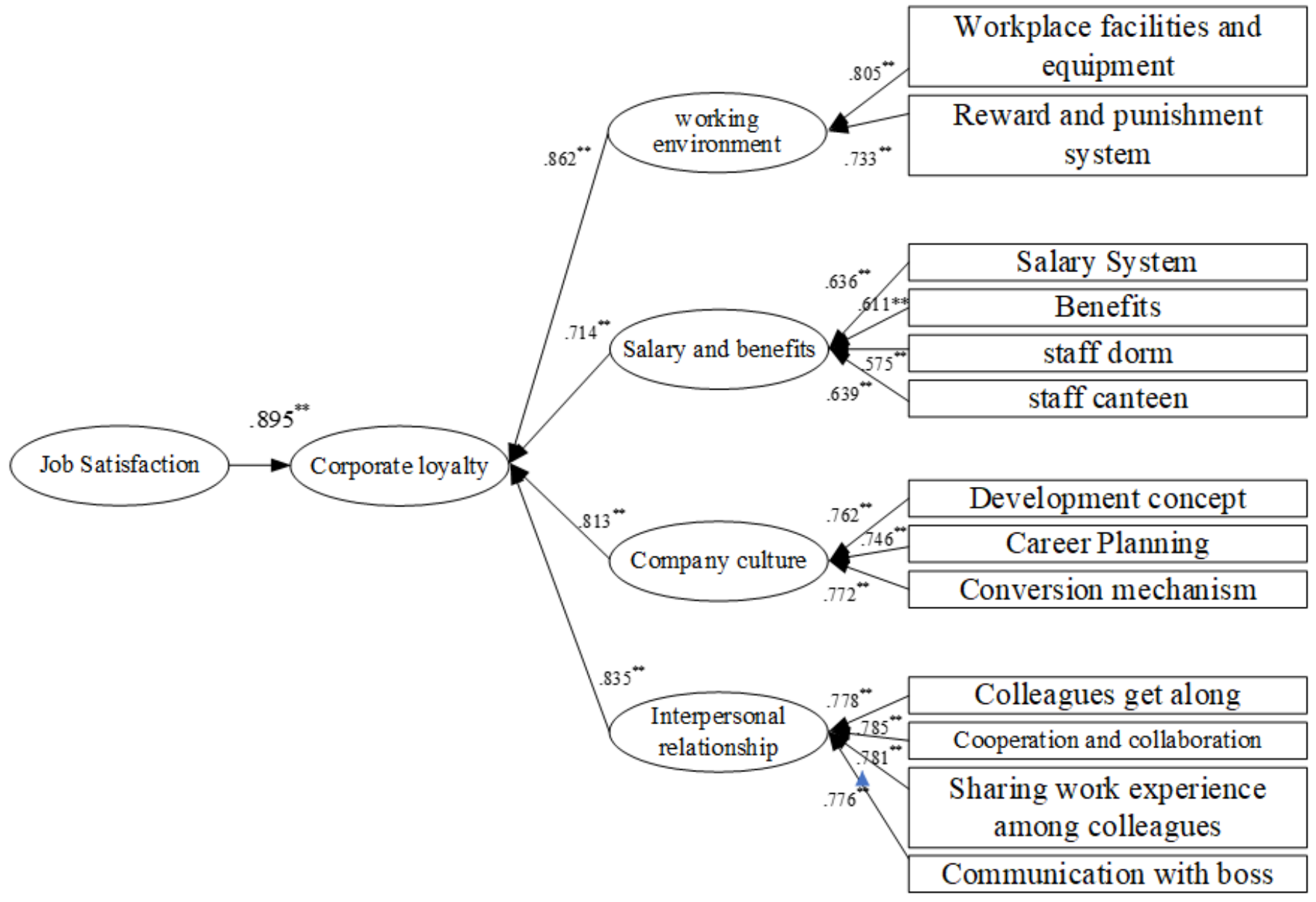

Figure 4 


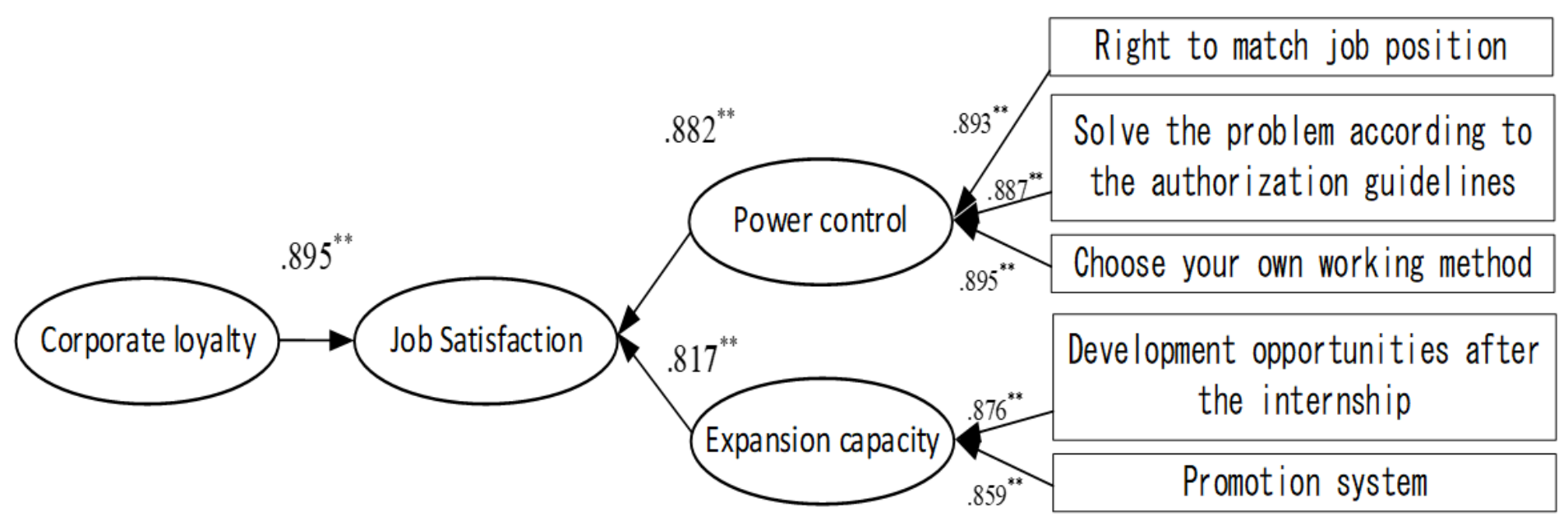

Figure 5

Correlation analysis of company loyalty and job satisfaction. * $p<0.01$ 